by Vladimir I. Davydov ${ }^{1}$, Brian F. Glenister ${ }^{2}$, Claude Spinosa ${ }^{3}$, Scott M. Ritter ${ }^{4}$, V. V. Chernykh ${ }^{5}$, B. R. Wardlaw 6 , and W. S. Snyder ${ }^{3}$

\title{
Proposal of Aidaralash as Global Stratotype Section and Point (GSSP) for base of the Permian System
}

\author{
1. All Russian Geological Research Institiute (VSEGEI), St. Petersburg, Russia \\ 2. University of Iowa \\ 3. Permian Research Institute, Boise State University, Idaho 82735 \\ 4. Brigham Young University \\ 5. Institute of Geology and Geochemistry, Ural Branch of Russian Academy of Sciences, Sverdlovsk, Russia \\ 6. U.S. Geological Survey
}

The base of the Permian System was originally defined (Murchison, 1841) in the Ural Mountains of Russia to coincide with strata marking the initiation of evaporite deposition, now recognized as the Kungurian Stage. Since that time, the base has been lowered repeatedly to include a succession of faunas with post-Carboniferous affinities. Problems in correlating different biotic provinces with the Urals standard have served to justify establishment of a plethora of regional chronostratigraphic references. Work of the Subcommission on Permian Stratigraphy (SPS) has focused on achievement of international standards and nomenclature for all subdivisions of the Permian System. The recent consensus (Jin et al.,1997) recognized three series, with standards for the Lower Permian Cisuralian Series located in the southern Ural Mountains of Kazakhstan and Russia, the Middle Permian Guadalupian Series references in the American southwest, and the Upper Permian Lopingian Series and Erathem boundary in South China.

The GSSP for the base of the Permian and basal Cisuralian Asselian Stage has been ratified by the International Union of Geological Sciences (IUGS) at Aidaralash Creek, Aktöbe (formerly Aktyubinsk) region, northern Kazakhstan. It is defined by the first occurrence of the conodont Streptognathodus isolatus in the $\mathrm{S}$. wabaunsensis chronocline. This level closely approximates the traditional boundary definitions based on ammonoid cephalopods and fusulinacean foraminifers.

\section{Introduction}

Since the orginal proposal of the Permian (Murchison, 1841), the base of the System has been subject to frequent regional redefinitions. Even in the type areas of the Ural Mountains, it has been lowered repeatedly following recognition of post-Carboniferous affinities of fossils from beneath the original (Kungurian) base of the System. As considered further herein, the Artinskian, Sakmarian, and Asselian were added in sequence beneath the Kungurian. Elsewhere, separate and largely independent chronostratigraphic standards evolved. As an example, problems in recognition of the Carboniferous/Permain boundary in Australia resulted in proposal of the "Kamilaroi" to embrace both systems (David, 1950), and sequences of local letter-designated stages for the Permian are still being utilized (e.g. Archbold et al., 1993) despite the fact that the Urals international standard has served effectively as a Western Australian reference for over one-half century (e.g. Miller, 1932). Similarly, in China the base of the Permian became stabilized at the unconformity

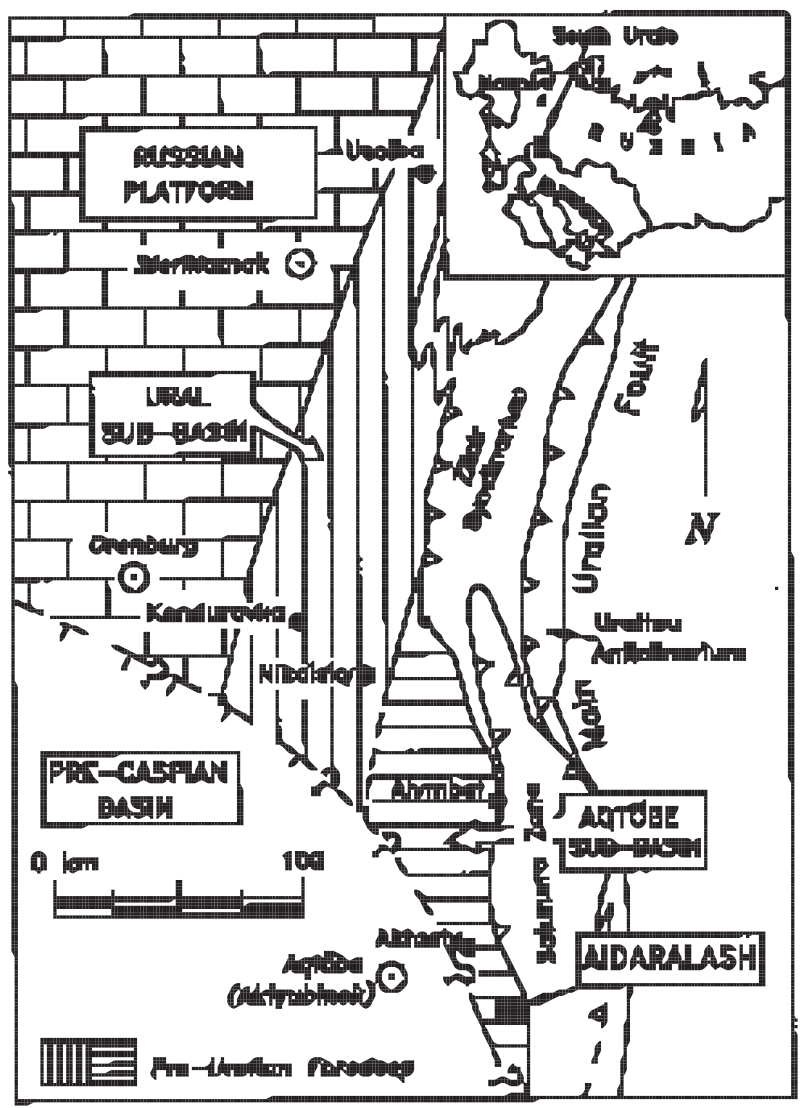

Figure 1 Upper Paleozoic tectonostratigraphic map of the southern Ural Mountains. Limestone pattern depicts the eastern margin of the Russian Platform. The vertical-and horizontalstriped patterns depict the Ural Sub-basin and the Aktöbe Subbasin respectively. Together they comprise Belsk Depression (not labeled) of the Pre-Uralian Foredeep. The two main stratigraphic sections considered for the GSSP for the base of Permian System, Aidaralash and Usolka, are identified. Other important Permo-Carboniferous sections of the region are indicated. The Aidaralash Creek section has now been ratified by the IUGS as the GSSP for the base of the Permian System. 
beneath the Chihsian, the approximate correlative of the Kungurian, without appropriate consideration of successive lowering of the base in the Urals. Such practices are counterproductive. So long as stratigraphers are content to utilize local references, there is no incentive to develop a common international language for geological time.

General recognition of the desirability of international standards for all intervals of geological time followed publication of the pioneering investigations of the Silurian-Devonian Boundary Committee (McLaren, 1977). The initial proposal of the Aidaralash section of northern Kazakhstan (Figure 1) as Global Stratotype Section and Point for the Base of the Permian System was approved informally by the International Congress on the Permian System of the World, Perm, Russia, in 1991. Following additional detailed investigations, the Aidaralash section (see Figure 2) was proposed formally (Davydov et al., 1995), and subsequently approved successively by the Carboniferous-Permian Boundary Working Group, Subcommission on Permian Stratigraphy, full Commission of the International Commission on Stratigraphy, International Union of Geological Sciences, and the 1996 Beijing meeting of the International Geolog- ical Congress (Glenister and Wardlaw, 1996). The present Episodes publication represents the final step in full ratification.

A stone and concrete marker with a plaque has been erected at the Aidaralash Creek section, Aktyubinsk (currently Aktöbe) marking the geographic and stratigraphic location of the GSSP (Figure 3C). An agreement has been reached (Summer 1997) with the Aktöbe Regional Geological Survey of Kazakhstan through Efim I. Knizhnik, Deputy Director, regarding accessibility of the site at Aidaralash; the Aktöbe Regional Geological Survey has graciously offered to provide the following:

- Organize official legislative action to establish a permanent scientific preserve for the GSSP site.

- Maintain accessibility to the Aidaralash section and site of the GSSP for all scientists and improve the access road from the main highway.

- Make improvements to road cut at the base of the section (Figure 3B).

- Erect a permanent monument to mark the location of the GSSP.

- Construct permanent markers identifying the position of individual beds.

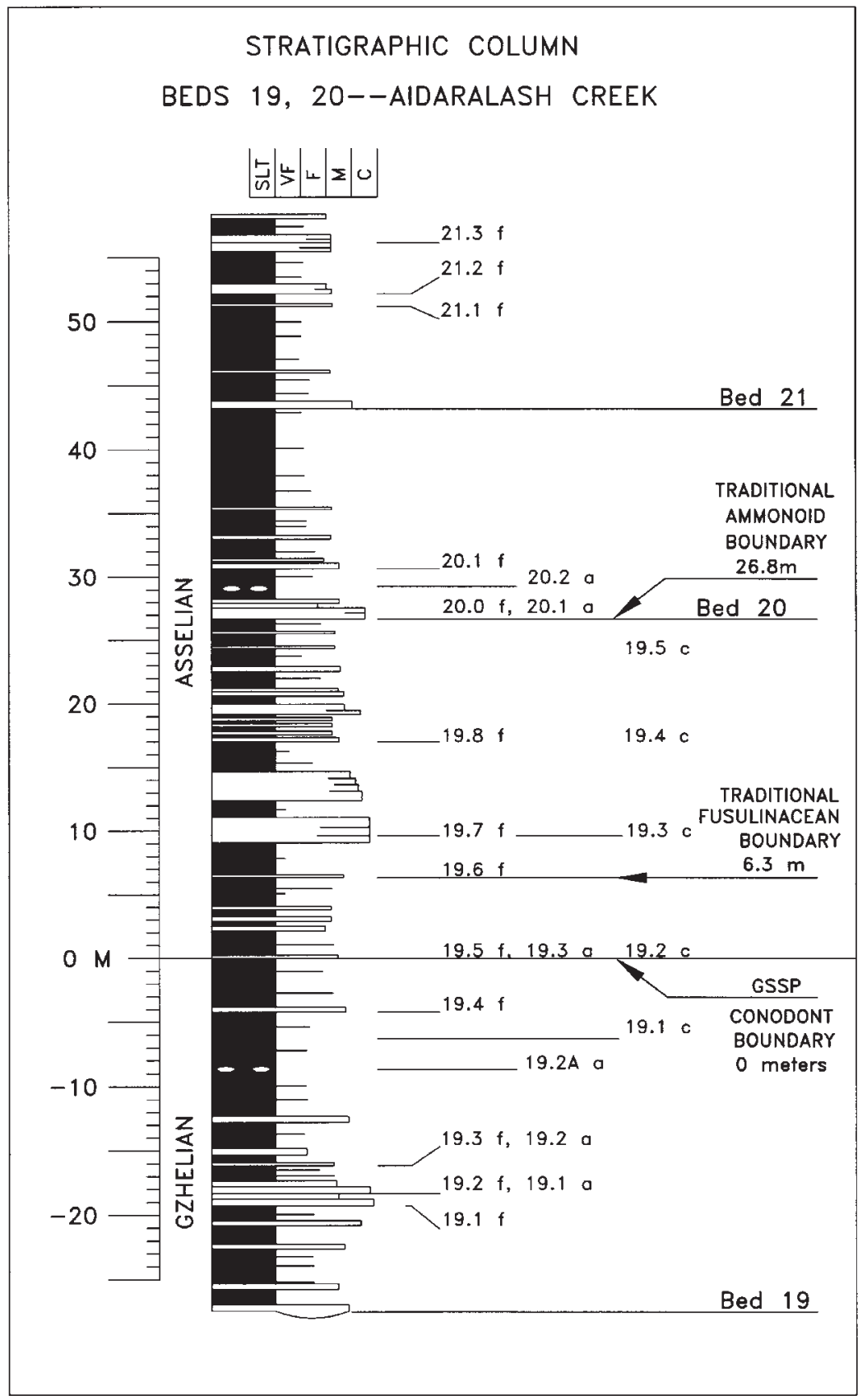

Figure 2 Stratigraphic column of portion of the section at Aidaralash Creek, Aktyubinsk (currently Aktöbe) region, southern Ural Mountains, northern Kazakhstan. Included are beds 19, 20 and portion of 21. Position of the Carboniferous/Permian boundary proposed on the basis of conodonts is included, as are previously proposed boundaries based on fusulinaceans and ammonoids. Bed numbers (e.g. 19) and subdivisions (e.g. 19.5) represent designations widely used in recent Soviet/Russian literature e. g., Chuvashov et al. (1993), Bogoslovskaya et al. (1995), and in the Guidebook for the excursion to the southern Ural Mountains (Permian Congress, Perm, 1991); " $a$ ", “ $f$ ", “c" indicate ammonoid, fusulinacean, and conodont occurrences, respec-tively. Zero meters mark the first occurrence of Streptognathodus isolatus, which developed from an advanced morphotype in the S. wabaunsensis chronocline. This arbitrarily chosen point in an evolutionary continuum has been ratified by the IUGS as defining the base of the Permian System. 


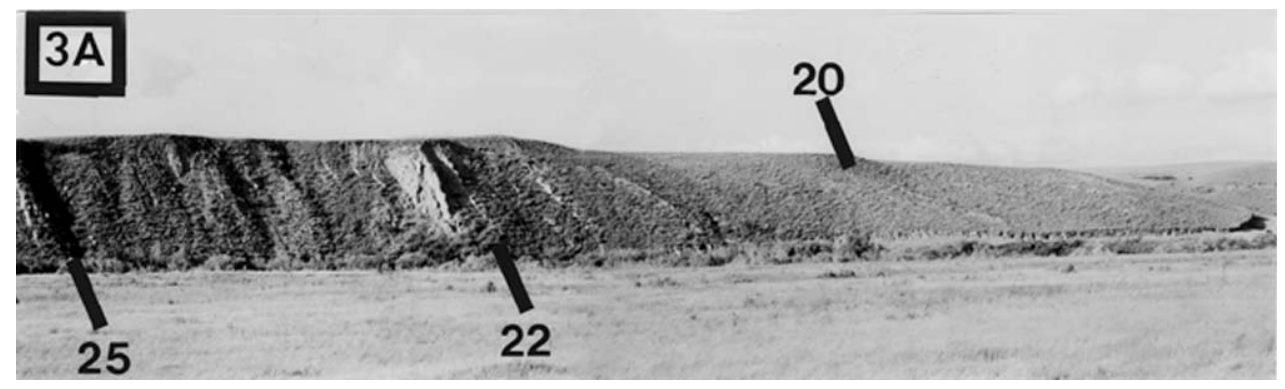

\section{B}
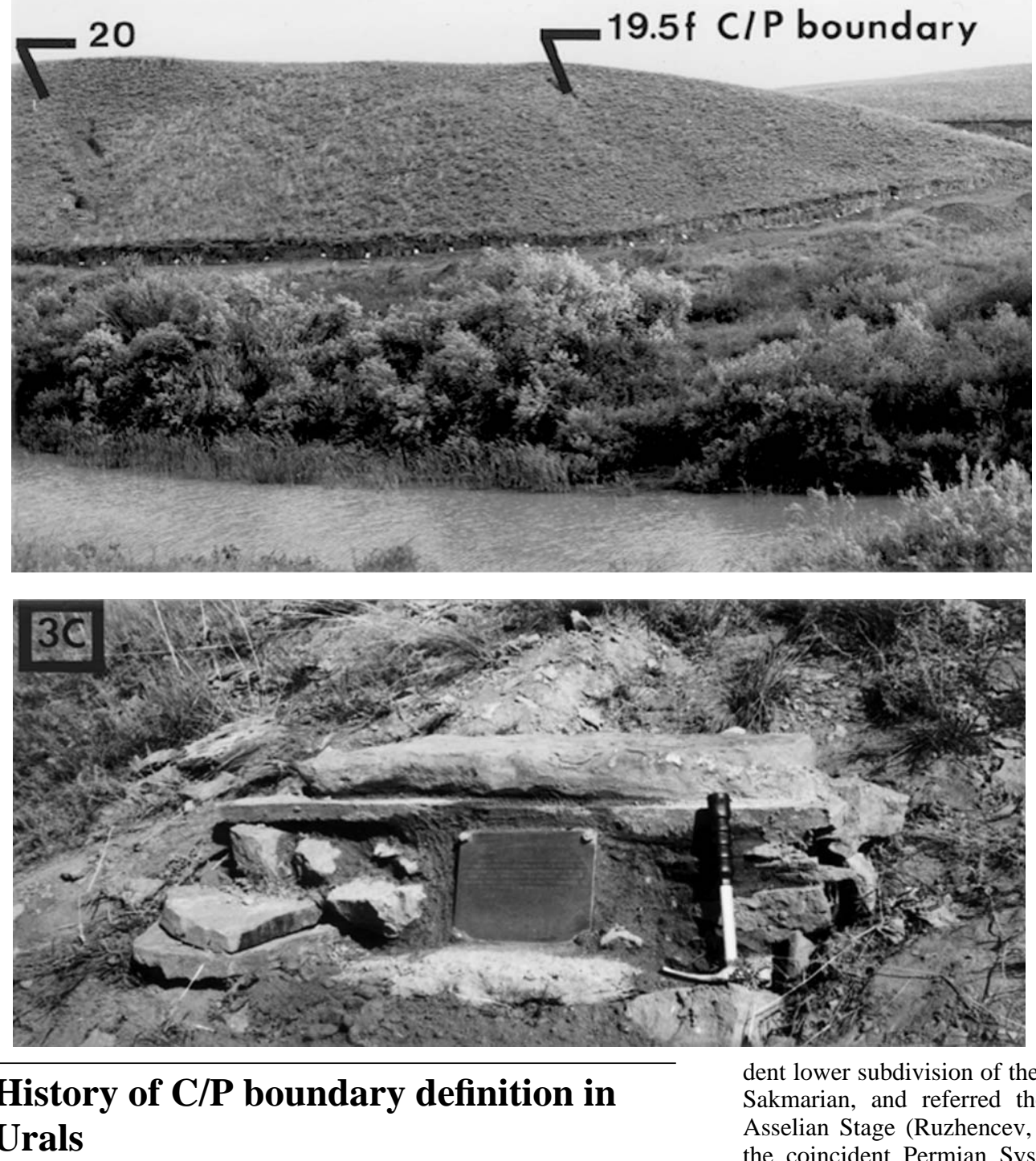

Dunbar (1940) provided a summary statement on the progressive early downward extension in definition of the base of the Russian Permian. In its original sense (Murchison, 1841), this base coincided with the initiation of evaporite deposition that is now referred to the Kungurian regional stage. Karpinsky (1874) identified clastic successions that Murchison had included in the British Millstone Grit as being younger, transitional between Carboniferous and Permian, and termed them the Artinskian Series. His subsequent classic study of the abundant ammonoid fauna (Karpinsky, 1889) led him to add the interval to the Permian. Further study, especially of ammonoids, permitted Ruzhencev (1936) to recognize the Sakmarian as an indepen-
Figure 3 Aidaralash Creek section Aktyubinsk (currently Aktöbe) region, southern Ural Mountains, northern Kazakh-stan. View is to the north, across vegetated creek bed. Nearly vertical beds are exposed in the west flank of an anticline; apparent dip of strata in photo-graph is to the east.

3A. General overview of the Asselian and Gzhelian portion of the section. Sequence boundaries (Snyder and Gallegos, 1997) are visible in strata corresponding to Beds 22 and 25. Sequence boundaries occurring at Beds 29 and 40 are not in the photo. 3B. Close-up of GSSP for the base of the Permian System and coincident Upper Carboniferous boundary. GSSP for the Carboniferous/Permian boundary is at the base of Bed $19.5 \mathrm{f}$, which is coincident with 19.3a and 19.2c (Figure 2). The road excavated at the base of the section exposes essentially every bed; covered intervals can be cleared readily. White dots along the road are sample bags.

3C. Close-up of boundary marker and temporary monument erected at Bed 19.5f in 1997. 
above, the latter reflecting first appearances of the characteristically Permian families Metalegoceratidae, Paragastrioceratidae and Popanoceratidae. The boundary favored by fusulinacean workers is almost coincident, separating the Ultradaixina bosbytauensisSchwagerina robusta Zone below from the Sphaeroschwagerina vulgaris aktjubensis-S. fusiformis Zone. More recently, a chronomorphocline of streptognathodid conodonts has offered a basis for an even more precise and widely recognizable boundary definition, marked by the appearance of the "isolated nodular" morphotype of Streptognathodus, S. isolatus Chernykh, Ritter, and Wardlaw (1997). These three boundary definitions are not competitively destructive, since for practical purposes they are coincident. As an example, at the Aidaralash section the conodont boundary occurs 27 $\mathrm{m}$ above the base of Bed 19, the fusulinacean boundary a mere few meters higher at $33 \mathrm{~m}$, and the ammonoid boundary that originally defined the base of the Asselian occurs $55 \mathrm{~m}$ above the base of Bed 19 at the 19/20 Bed boundary (Figure 2).

\section{Aidaralash as GSSP}

\section{Introduction}

Many C/P boundary sections in the southern Ural Mountains of Russia and Kazakhstan have been studied in detail, and can be correlated confidently with the newly established boundary stratotype along Aidaralash Creek. However, each of these other sections has attributes that detract from its scientific merit to serve as the GSSP. For example, the classic condensed section along the Usolka River, deposited along the margin of the Pre-Uralian Foredeep (Figure 1), is exceptionally rich in conodonts; these afford precise correlation with Aidaralash (Chuvashov et al., 1993), but other critical fossil groups are only rarely associated.

The Aidaralash Creek section is located in the Aktöbe (formerly Aktyubinsk) region of the southern Ural Mountains of northern Kazakhstan, approximately $50 \mathrm{~km}$ southeast of the city of Aktöbe (Figure 1). The stratigraphic section there is readily accessible, and is characterized by an uninterrupted succession of strata across the C/P boundary that contain abundant and well-preserved conodont, ammonoid, and fusulinacean faunas. Associated microfossils, such as radiolarians, small foraminifers, and palynomorphs should provide additional important bases for correlation, and paleomagnetics have been investigated (Khramov and Davydov, 1984, 1993).

Current consensus on the position of the $\mathrm{C} / \mathrm{P}$ boundary has evolved, in large part, from studies of ammonoids (Ruzhencev, 1936, 1945, 1950, 1951, 1952, 1954) and fusulinaceans (RauserChernousova, 1940; Rosovskaya, 1952) from the Urals. Ruzhencev investigated many sections, but principal among them, and the focus to the present statement, was Aidaralash Creek. Resulting publications (Ruzhencev, 1950, 1951, 1952) contain detailed documentation of the succession of ammonoids and fusulinaceans, and together with the sedimentologic data of Khvorova (1961) provide the framework for the modern understanding of regional Late Paleozoic stratigraphy. A series of recent investigations addressed placement of the C/P boundary (e.g. Pnev et al., 1978; Davydov and Popov, 1986; Bogoslovskaya et al., 1995), as have numerous reports from recent issues of Permophiles (e.g. ${ }^{19}$, November 1991: Utting, p. 2-5; \#21, November 1992: Jin, p. 3-4; Wardlaw, p. 5-7; Nassichuk and Rui Lin, p. 11-15; Henderson, p. 15-16; \#22, June 1993: Glenister, p. 2-5; Chuvashov, Chernykh and Mizens, p. 11-16; \#23, November 1993: Utting, p. 1-4; Davydov, p. 5-8; Spinosa et al., p. 9-11; \#24, June 1994: Ross and Ross, p. 3-6; \#25, November 1994: Glenister and Wardlaw, p. 2-3; Chernykh and Ritter, p. 4-6). Collectively these investigations have led to formal ratification of the first appearance of the conodont Streptognathodus isolatus, $27 \mathrm{~m}$ above the base of Bed 19 in the Aidaralash section, as the GSSP for the base of the Permian System.

\section{Sequence stratigraphy along Aidaralash Creek}

Upper Paleozoic strata of Aidaralash Creek were deposited on a narrow, but persistent, shallow marine shelf that formed the western boundary of the orogenic highlands. The sequence stratigraphy reflects repeated shelf to fluvial-deltaic cycles. Our general mapping and detailed measurements of stratigraphic sections are built on the pioneering work of Ruzhencev $(1951,1952,1956)$ and Khvorova (1961). Only a summary is presented here.

Permo-Carboniferous strata exposed along Aidaralash Creek can be described using a series of lithofacies. A mudstone-siltstone (SLT, Figure 2) facies, containing abundant fine plant debris, is interpreted as the background, offshore sediment; this facies reflects the abundant terrigenous input from deltaic sources. Very fine, fine, medium, and gravelite sand facies (VF-C, Figure 2) represent event beds. Some sandstone beds display simple grading with rippled tops which may represent unreworked sediment gravity flows. However, most of the sandstones occur as horizontally stratified, amalgamated beds 5 to $30 \mathrm{~cm}$ thick; internal stratification is defined by 0.5 to $5 \mathrm{~cm}$ thick graded intervals with common ripples. These horizontally stratified sandstone beds are interpreted as storm deposits or as wave- and storm-reworked sediment gravity flows. Paleocurrent data suggest that a large and persistent delta complex developed to the northeast and supplied sand that was periodically transported southwestwardly to the Aidaralash area. Preservation of storm beds and hummocky cross stratification suggests that much of the section was deposited below fair weather wave base. The coarse grain size and sedimentary structures within gravelite beds (C, Figure 2 ) suggest sediment gravity flow deposition and wave current reworking of the upper portions of the beds. Sandstone beds occur in thickening upward cycles with or without discernable coarsening. Fusulinaceans tend to occur within the base of sandstone beds. Polymictic pebble to cobble conglomerates form conspicuous fining-upward successions 10 to $50 \mathrm{~m}$ thick. These interbedded conglomerates and sandstones are typically poorly cemented. Limestone and wellindurated sandstone clasts predominate, but also included are metamorphic, granitic, rhyolitic to andesitic volcanic, and greenstone clasts. Basal contacts are typically scoured into underlying shelf sandstone successions.

Conglomerate beds mark the most obvious Aidaralash sequence boundaries. These fluvial-deltaic conglomerate-sandstone successions grade upward into transgressive marginal marine sequences (beach and/or upper shoreface), to a maximum flooding unit (typically with ammonoids, conodonts, and radiolarians). This gradation usually occurs within a stratigraphic thickness of a few to $10 \mathrm{~m}$. The maximum flooding zone is overlain by a regressive sequence (offshore to shoreface to delta front), which in turn is capped by an unconformity with the overlying conglomerate. The first conglomerate in the stratotype section occurs $685 \mathrm{~m}$ above the base of the Permian boundary and represents the first significant break within the Cisuralian stratigraphic section at Aidaralash Creek. Possible sequence boundaries (Figure 3A) occur $72 \mathrm{~m}$ (Bed 22), $118 \mathrm{~m}$ (Bed 25) and $286 \mathrm{~m}$ (Bed 29) stratigraphically above the Carboniferous-Permian boundary; however, there is no evidence of subaerial exposure at these beds. No sequence boundary is exposed within the Gzhelian portion of the section. Therefore, no unconformity occurs within the section from $555 \mathrm{~m}$ below to $685 \mathrm{~m}$ above the Carboniferous-Permian boundary, and the first sequence boundary occurs at Bed 22 (72 $\mathrm{m}$ above the boundary).

\section{Ammonoid biostratigraphy}

Ruzhencev $(1950,1952)$ placed the boundary between the Orenburgian and Asselian stages at the contact between Beds 19 and 20 in the Aidaralash Creek section (Figure 2), and subsequently this became generally accepted as the Carboniferous/Permian boundary. In a recent reexamination of the ammonoid biostratigraphy of this section, Bogoslovskaya et al. (1995) supported Ruzhencev's choice, and documented a greater level of ammonoid diversity than previously known from there. They recognized 9 species from Bed 19 
$(19.2 \mathrm{c}=19.3 \mathrm{a}$, Figure 2$)$ and 13 from Bed $20(20.0 \mathrm{f}=20.1 \mathrm{a}$, Figure 2). A consequential turnover at that level was suggested, including termination of the Prouddenites-Uddenites lineage at the top of Bed 19, and introduction of two important Permian species, Svetlanoceras primore and Prostacheoceras principale in Bed 20.

Several ammonoid lineages can be identified as crossing the C/P boundary (Bogoslovskaya et al., 1995). The ancestral species of Prostacheoceras, $P$. principale from Bed 20, appears to be closely related to the Carboniferous Vidrioceras but is a more abvanced representative of the group. Artinskia irinae from Bed 19 and Artinskia kazakhstanica from Bed 20 constitute a possible chronocline that crosses the C/P boundary. Above Bed 19 several Carboniferous genera are represented by new Permian species, including Daixites antipovi, Prothalassoceras serratum, Glaphyrites angustilobatus, and G. rarus, and this boundary corresponds to that between the Shumardites-Vidrioceras Genozone below and the Svetlanoceras-Juresanites Genozone above (Bogoslovskaya et al., 1995). These ammonoid changes at the boundary of Beds 19 and 20, therefore, offer advantages for serving in definition of the GSSP, notably that the new appearances seem to usher in distinctive ammonoids with good correlation potential. There are serious problems, however:

1) ammonoids of critical stratigraphic significance are rare; those that represent the only plausible chronocline, Artinskia irinae-A. kazakhstanica, are scarce indeed;

2) there exists an interval of $27.5 \mathrm{~m}$ between the last documented Carboniferous ammonoid occurrence at Bed 19/5 (Bed 19.5f = 19.3a, Figure 2) and the first Permian occurrence in Bed 20 (both Bogoslovskaya et al., 1995).

3) ammonoid genera from the Urals may occur elsewhere, but most species appear to be endemic.

\section{Fusulinacean biostratigraphy}

Fusulinacean distributions at the Aidaralash section were documented by Ruzhencev $(1950,1952)$ in connection with definition of the Orenburgian/Asselian boundary. He noted the first occurrence of inflated "Schwagerina" (= Sphaeroschwagerina) at the base of Bed 20 at Aidaralash, coincident with the appearance of distinctive new Permian ammonoid families and genera. Subsequently, Pnev et al. (1978) reported "Sphaeroschwagerina" from Bed 17, and for a time the C/P boundary was lowered to the base of Bed 10 (base of the Ultradaixina bosbytauensis-Schwagerina robusta fusulinacean Zone). However, restudy of the "Sphaeroschwagerina" from Bed 17 by a colloquium of specialists resulted in reassignment to Licharevites, a similarly inflated genus that occurs in Beds 14 through 26 at Aidaralash and is widespread from Spitsbergen to China.

Recent studies of fusulinaceans from Aidaralash have revealed that changes in the dominant lineages across the boundary interval are gradual (Davydov et al., 1992). However, the base of the Sphaeroschwagerina vulgaris aktjubensis-S. fusiformis Zone can be identified precisely and correlated confidently from Spitsbergen (Nilsson and Davydov, 1997) through the Russian Platform, the Urals, Central Asia, China and Japan (Davydov et al., 1994 ). For practical purposes it corresponds to the boundary between the Orenburgian and Asselian as defined by Ruzhencev. At Aidaralash, it coincides with the contact between Beds 19/5 and 19/6 (19.5f and 19.6f, Figure 2) $6 \mathrm{~m}$ above the conodont boundary and $22 \mathrm{~m}$ below the original ammonoid boundary. At this horizon, Ultradaixina practically disappears, Schellwienia becomes scarce, and species of Sphaeroschwagerina first appear. Other fusulinacean lineages, such as Schwagerina, Dutkevitchia, Rugosochusenella and Ocellina, also intersect this boundary as well. Additional data from approximately 10,000 oriented thin sections from Aidaralash may eventually provide important morphometric bases for refined correlation.

Despite their undoubted value in correlation, there would be significant problems in defining the $\mathrm{C} / \mathrm{P}$ boundary on fusulinaceans:

1) fusulinaceans were benthic organisms, and their distribution is somewhat provincial;

2) most were confined to shallow water carbonate facies, but they may have been redeposited in deeper turbidite facies; rework- ing from older deposits, although not documented for Aidaralash, cannot be excluded;

3) taxonomy is in a state of flux, and regional interpretations differ substantially.

\section{Conodont biostratigraphy}

A number of Russian specialists examined conodont successions from Aidaralash as well as the basinal shales at Usolka, and a summary analysis was provided by Davydov et al. (1992). More detailed investigations have followed, including refined sampling of the $\mathrm{C} / \mathrm{P}$ boundary interval (Chernykh and Ritter, 1994, 1997). These latter authors collected a total of 53 samples from all suitable horizons within Beds 3 through 37 of the Aidaralash section, and reported many horizons yielding well-preserved conodont elements with abundances ranging from 5 to over 100 specimens per kilogram. Small numbers of reworked Late Devonian and Moscovian conodont elements were noted in some faunas; these are generally recognizable on preservation as well as identity. The Conodont Alteration Index is 1.5-2.0.

Conodont faunas throughout the sampled interval at Aidaralash, Beds 3 through 37, are dominated by Pa elements of Streptognathodus. The C/P boundary is defined (Chernykh and Ritter, 1994) by the first appearance of "isolated-nodular" morphotype, S. isolatus Chernykh, Ritter, and Wardlaw (1997), which developed from an advanced "non-isolated nodular" morphotype in the S. "wabaunsensis" chronocline. This arbitrarily-chosen point in the evolutionary continuum lies $27 \mathrm{~m}$ above the base of Bed 19 at Aidaralash, and can be recognized readily elsewhere. In the basinal shales at Usolka, it occurs in the lower part of Bed 16 (Chuvashov et al., 1990), and in the cyclic successions of the American Midcontinent it is identified in the Glenrock Limestone Member and the base of the overlying Bennett Shale, Red Eagle Formation of Kansas (Chernykh and Ritter, 1994; Boardman et al., 1994; Ritter, 1995; Wardlaw, Boardman and Nestell, in press). Some nomenclatural problems have yet to be resolved, but it appears that specific names proposed in the two systematic papers (Ritter, 1995; Wardlaw et al., in press) will be acceptable. The first occurrences of Streptognathodus invaginatus and $S$. nodulinearis, also morphotypes of the "wabaunsensis" morphocline, nearly coincide with the first occurrence of $S$. isolatus in many sections and can be used as accessory indicators for the boundary. It should be emphasized that although an arbitrarily-chosen point within a single conodont chronocline is being chosen for definition of the boundary, every other line of evidence (biological, sedimentological, geochemical, geophysical) should and actually is being utilized to effect correlation to that point.

\section{Magnetostratigraphy}

Utilization of magnetostratigraphy to aid in recognition of the $\mathrm{C} / \mathrm{P}$ boundary is difficult because the Kiama Hyperzone is characterized by long stable intervals of reverse polarity separated by only narrow subzones of normal polarity. However, Khramov and Davydov (1993) reported that most of the Ultradaixina bosbytauensis-Schwagerina robusta fusulinid zone just below the $\mathrm{C} / \mathrm{P}$ boundary in Aidaralash is characterized by normal polarity. This same stratigraphic/ polarity relationship occurs in the Nikolsky section of the southern Urals and the Belaya River section of the northern Caucasus (Khramov and Davydov, 1984), and in the Ivano-Darievka section in Donets Basin (Khramov, 1963; Davydov, 1986). It may also correspond to the normally polarized magnetic zone established within the Manebach Formation of the Thuringian Forest (Menning, 1987). Thus the normal polarity zone may prove useful in characterizing the interval immediately below the $\mathrm{C} / \mathrm{P}$ boundary. 


\section{Summary and formal proposal}

In summary, the stratigraphic section at Aidaralash Creek fulfills, better than any other known section, all of the basic requirements for effective service as GSSP for the base of the Permian System. It enjoys historic priority and excels in overall scientific merit. Exposure and accessibility presently are adequate and both will be improved and maintained by the Aktöbe Regional Geological Survey of Kazakhstan. Future access will be guaranteed by means of legislative action to create a scientific preserve. The state of knowledge for relevant geologic characteristics for the section is advanced. Evidence from sedimentology and analysis of the conodont chronomorphocline confirm that there is no significant hiatus in sedimentation across the boundary interval. Redistribution in space of fusulinaceans is probable, and advantageous, but with the exception of a small percentage of conodont specimens, there is no evidence of reworking in time. Conodonts provide a chronomorphocline across the boundary that serves for definition, and similar clines probably occur in the fusulinaceans. For practical purposes, historic boundaries for ammonoids and fusulinaceans are coincident with that proposed in the conodont definition of the C/P boundary.

For the reasons cited, the first occurrence of Streptognathodus isolatus within the S. "wabaunsensis" conodont chronocline, $27 \mathrm{~m}$ above the base of Bed 19, Aidaralash Creek, northern Kazakhstan, is hereby confirmed as GSSP for the base of the Permian System. Sections adjacent to Aidaralash in the south Urals, such as Usolka, will serve as subsidiary references. However, ICS Guidelines (Cowie et al., 1986) discourage formal proposal of parastratotypes.

\section{Acknowledgements}

We express our gratitude to Dora Gallegos, Albertson College of Idaho, for reviewing the manuscript and to Dale Kerner, Boise State University, for the photograph in Figure 3C. National Science Foundation (Grant EAR-9219428; Petroleum Research Fund PRF30215ac8) provide funding for research during the years 1991, 1993 and 1995).

\section{References}

Archbold, N W, Dickins, J M and Thomas, G A , 1993, Correlation and age of Permian marine faunas in Western Australia: Geol. Surv. West. Australia Bull., 136, p. 11-18.

Boardman, D R, Miller, K, and Nestell, M K, 1994, Carboniferous-Permian boundary strata in the Manhattan, Kansas region: Spring Field Trip 1994, Midcontinent Section SEPM, Pennsylvanian Working Group, 60 p., 17 pls.

Bogoslovskaya, M F, Leonova, T B, and Skholin, A A, 1995, The Carboniferous-Permian boundary and ammonoids of the Aidaralash section, southern Urals: Jour. Paleontology, 69, p. 288-301.

Chernykh, V V, and Ritter, S M, 1994, Preliminary biostratigraphic assessment of conodonts from the proposed Carboniferous-Permian boundary stratotype, Aidaralash Creek, northern Kazakhstan: Permophiles 25, p.4-6.

Chernykh, V V, and Ritter, S M, 1997, Streptognathodus (Conodonta) at the Carboniferous-Permian boundary stratotype section, Aidaralash Creek, northern Kazakhstan: Jour. Paleontology, v. 71, p. 459-474.

Chernykh, V V, Ritter, S M, and Wardlaw, B R, 1997, Streptognathodus isolatus new species (Conodonta): Proposed index for the CarboniferousPermian boundary: Jour. Paleontology, v. 71, p. 162-164.

Chuvashov, B I, Chernykh, V V, and Mizens, G A, 1993, Zonal divisions of the boundary deposits of Carboniferous and Permian in sections of different facies in the south Urals: Permophiles 22, p. 11-16.

Chuvashov, B I, Dupina, G V, Mizens, G A, and Chernykh, V V, 1990, Report on Upper Carboniferous and Lower Permian sections, western slope of the Urals and pre-Urals: Uralian Branch U.S.S.R. Acad. Sci., Sverdlovsk, 368p.

Cowie, J W. Ziegler, W, Boucot, A J, Bassett, M G, and Remane, J, 1986, Guidelines and statutes of the International Commission on Stratigraphy (ICS): Cour. Forsch. Inst. Senckenberg 83,14p.

David, T W E, 1950, The Geology of the Commonwealth of Australia, W. R. Browne (ed.): Edward Arnold Publishing, London, v.1, 714p.
Davydov, V I, 1986, Precise definition of Carboniferous/Permian boundary in Donets Basin and the North Caucasus according to paleomagnetic criteria: Sov. Geol., 12, p. 74-76.

Davydov, V I, Barskov, I S, Bogoslovskaya, M F, Leven, E Y, Popov, A V, Akhmetshina, L Z, and Kozitskaya, R I, 1992, The Carboniferous-Permian boundary in the former USSR and its correlation: Int. Geol. Review, v. 34, no. 9, p. 889-906

Davydov, V I, and Popov, A V, 1986, The section of the Upper Carboniferous and Lower Permian deposits of south Urals: In Boundary Deposits of the Urals, Pre-Urals Area and Central Asia, p. 29-33.

Davydov, V I, Barskov, I S, Bogoslovskaya, M F, and Leven, E Y, 1994, Carboniferous-Permian boundary in stratotype sections of the southern Urals and its correlation: Stratigraphy and Geological Correlation, 2, 3:32-45 (In Russian and English).

Davydov, V I, Glenister, B F, Spinosa, C, Ritter, S M, Chernykh, V V, Wardlaw, B R, and Snyder, W S, 1995, Proposal of Aidaralash as the GSSP for the base of the Permian System, Permophiles 26, p. 1-9.

Dunbar, C O, 1940, The type Permain: its classification and correlation: Bull. Amer. Assoc. Petrol. Geol. 24, p. 237-281.

Glenister B F, and Wardlaw B R, 1996, Report of the Carboniferous-Permian Boundary Working Group, Permophiles 29, p. 4-5.

Jin, Yu-gan, Wardlaw, B R, Glenister, B F, and Kotlyar, G V, 1997, Permian chronostratigraphic subdivisions: Episodes, v. 20, p. 10-15.

Karpinsky, A P, 1874, Geological investigation in the Orenburg area: BergJour., II, Verhandl. Miner. Gesellsch. IX, p. 13-31.

Karpinsky, A P, 1889, Über die Ammoneen der Artinsk-Stufe und einige mit denselben verwandte carbonische Forman: Mem. Acad. Imp. Sci. StPetersburg, ser, 7, 37(2), 104p.

Khramov, A N, 1963, The Paleozoic paleomagnetism: Leningrad, Nedra, p. 1-283.

Khramov, A N, and Davydov, V I, 1984, Paleomagnetism of Upper Carboniferous and Lower Permian in the south of USSR and the problems of structure of the Kiama Hyperzone: Transactions of VNIGRI, p. 55-73.

Khramov, A N, and Davydov, V I, 1993, Results of paleomagnetic investigations. Permain System: Guides to Geol. Excursions in the Uralian Type Localities. Occasional Publ. ESRI, New Series, no. 10, p. 34-42.

Khvorova, I V, 1961, Flysch and lower molasse formations of southern Urals: Transactions of Geological Institute of Academy of Sciences of USSR, Issue 37, p. 1-352.

McLaren , D J, 1977, The Silurian-Devonian Boundary Committee. A final report-The Silurian-Devonian Boundary: IUGS Ser. A, 5, 35p., Stuttgart.

Menning, M, 1987, Magnetostratigraphy, in Lutzner, H (ed.), Sedimentary and Volcanic Rotliegendes of the Saale Depression: Excursion Guidebook Symp. Rotliegendes in Central Europe. Centr. Inst. Phys. Earth, Potsdam, p. 92-96.

Miller, A K, 1932, Metalegoceras jacksoni of the Irwin River Coalfield, Western Australia: Amer. Jour. Sci. 24, p. 433-442.

Murchison, R I, 1841, First sketch of the principal results of a second geological survey of Russia: Phil. Mag., Ser. 3, 19, p. 417-422.

Nilsson, I, and Davydov, V I, 1997, Fusulinid biostratigraphy of Upper Carboniferous Gzhelian and Lower Permian (Asselian-Sakmarian) succession of Spitsbergen, Arctic Norway. Permophiles No. 30, p. 18-27.

Peterson, D N, and Nairn, A E M, 1971, Paleomagnetism of Permian redbeds from the southwestern United States: Geophys. J. R. Astronom. Soc. vol. 23, p. 191-207.

Pnev., V P, Polozova, A N, Pavlov, A M, and Faddeyeva, I Z, 1975, Stratotype section of the Orenburgian Stage, south Urals (Nikolskoye village): Izvest. Akad. Nauk SSSR, Ser. Geol. 6, p. 100-109.

Pnev, V P, Polozova, A N, Pavlov, A M and Faddeyeva, I Z , 1978, Aidaralash section is a key section of the Asselian Stage: Trans. Leningrad Mining Inst. 73, p. 90-98.

Rauser-Chernousova, D M, 1940, Stratigraphy of the Upper Carboniferous and the Artinskian Stage of the western slope of the Urals and data on the fusulinid faunas: Akad. Nauk SSSR, Inst. Geol. Nauk Trudy, Ser. Geol. 7 (2), p. 37-104.

Resolutions of the Interdepartmental Stratigraphic Committee of Russia and its Permanent Commissions - Resolution on Carboniferous/Permian boundary. St. Petersburg, 1992, p. 52-56.

Ritter, S M, 1995, Upper Missourian-Lower Wolfcampian (Upper Kasimovian-Lower Asselian) conodont biostratigraphy of the Midcontinent, U.S.A.: Jour. Paleontology, v. 69, p. 1139-1154.

Rosovskaya, S E, 1952, Fusulinids of the Upper Carboniferous and Lower Permian of the Southern Urals: Trans. Palaeont. Inst. Acad. Sci. USSR, v. 40, p. 5-50.

Ross, C A, and Ross, J R P, 1987, Late Paleozoic sea levels and depositional sequences: Cushman Found. Foram. Res., Spec. Publ. 24, p. 137-149. 
Ruzhencev, V E, 1936, New data on the stratigraphy of the Carboniferous and Lower Permian deposits of the Orenburg and Aktyubinsk regions: Prob. Sov. Geol. 6, p. 470-506.

Ruzhencev, V E, 1945, Structure-facies analysis of the Sakmarian-Artinskian deposits of the Bashkirian Pre-Urals and its significance for petroleum exploration: Nauk SSSR, Paleont. Inst. Trudy 29, 220p.

Ruzhencev, V E, 1951, Lower Permian ammonoids of the south Urals. I . Ammonoids of the Sakmarian Stage: Akad. Nauk SSSR, Paleont. Inst. Trudy 33, 188p.

Ruzhencev, V E, 1952, Biostratigraphy of the Sakmarian Stage in the Aktyubinsk region of the Kazakh SSR: Akad. Nauk SSSR, Paleont. Inst. Trudy 42, 90p.

Ruzhencev, V E, 1954, Asselian Stage of the Permian System: Doklady Akad. Nauk SSSR 99(6), p. 1079-1082.

Ruzhencev, V E, 1956, Lower Permian ammonoids of the south Urals. II. Ammonoids of the Artinskian Stage: Akad. Nauk SSSR, Paleont. Inst. Trudy 60, 275p.

Snyder, W S, and Gallegos D M, 1997, Sequence Stratigraphy along Aidaralash Creek and the Carboniferous/Permian GSSP, Permophiles 30, p. 811.

Snyder, W S, Spinosa, C, Davydov, V I, and Belasky, P. 1994, Petroleum geology of the Pre-Uralian Foredeep with reference to the Northeastern Pre-Caspian Basin: Int. Geol. Review 36, p. 452-472.

Wardlaw, B R, Boardman, D R, and Nestell, M K, in press, Conodont systematic, in Boardman, Nestell and Wardlaw, Uppermost Pennsylvanianlowermost Permian conodont biostratigraphy of Kansas and Oklahoma: Kansas Geol. Surv. Bull.

Vladimir I. Davydov is Senior Scientist of the All Russian Geological Research Institute (VSEGEI), and is currently visiting Research Professor at the Permian Research Institute, Department of Geosciences, Boise State University. Since 1977 he has concentrated on Upper Paleozoic stratigraphy and fusulinid biostratigraphy in various regions of CIS as well as Arctic Norway and most recently in the Western U.S. and Carnic Alps. His scientific background also includes research interest in magnetostratigraphy, biogeochemistry, paleoclimatology, graphic correlation, and sequence stratigraphy. $\mathrm{He}$ is a Corresponding Member of the Sucommission on Permian Stratigraphy.

Brian F, Glenister is A. K. Miller Professor of Geology, University of Iowa. Trained in Australia, he has served in American academia for the past 38 years. His research on Paleozoic cephalopods, especially ammonoids and conodonts provides background for active participation in International Commission on Stratigraphy deliberations ranging from the Devonian through Triassic. Most recently, he served as Chair of the Subcommission on Permian Stratigraphy and working groups for the Carboniferous-Permian Boundary and Middle Permian Guadalupian Series. He is also Corresponding Member of the Subcommission on Carboniferous Stratigraphy and Voting Member of the Permian-Triassic Boundary Working Group.
Claude Spinosa is co-director of the Permian Research Institute, Boise State University and Professor in the Department of Geosciences. He studied ammonoid biostratigraphy and paleobiology at the University of Iowa. He has worked on the biology of Recent Nautilus in the central equatorial Pacific Ocean and Permian ammonoid biostratigraphy of North America and the Ural Mountains. Presently he serves as Secretary of the Subcommission on Permian Stratigraphy and editor of its newsletter, Permophiles.

Scott M. Ritter is a graduate of Brigham Young University (BYU) and post-graduate of the University of Wisconsin-Madison. Since 1991, he has been teaching stratigraphic paleontology and carbonate sedimentology at BYU. His research focuses upon the conodont biostratigraphy and sequence stratigraphy of Late Carboniferous-Early Permian strata in the USA and southern Urals. He was Chairman of the South-central Section of the Geological Society of America and is currently a Corresponding Member of the Subcommission on Permian Stratigraphy.

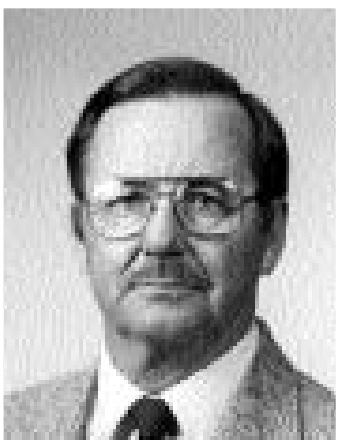

Bruce R. Wardlaw is Chief Paleontologist of the U. S. Geological Survey, current Chair of the Subcommission on Permian Stratigraphy, and chief of a large ecosystem history, ground water, and stratigraphy project to better assess restoration values for the South Florida ecosystems. He has worked on Permian brachiopods, Carboni-ferous-Triassic conodonts, carbonate petrology and stratigraphy. His current interest is the refined conodont biostratigraphy of Upper Carboniferous and Permian.
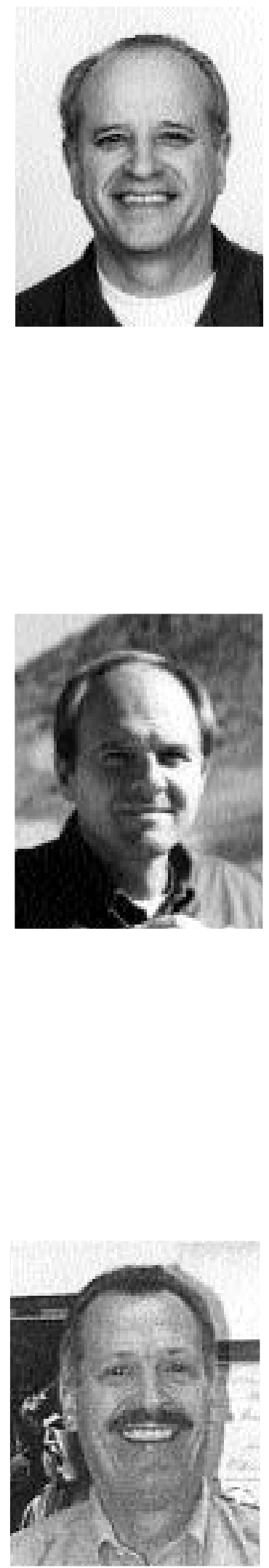
Valerie V. Chernykh received his $P h$. D. from the Mining Institute of the Geological Faculty in Sverdlovsk. He has been at the Institute of Geology and Geochemistry of the Ural Branch of the Russian Academy of Sciences since 1981, where he presently holds the position of Leading Scientist in the Laboratory of Stratigraphy and Paleontology. In 1989 he received the D. S. on the theme" Methodological Basis and Practice of Construction of Zonal Biochronological Scales". His research interests include: evolutionary biology, micropaleontology, general and applied stratigraphy, theory of systems. More recently his research has been focused on Devonian through Permian stratigraphy and micropaleontology of Ural Mountains.

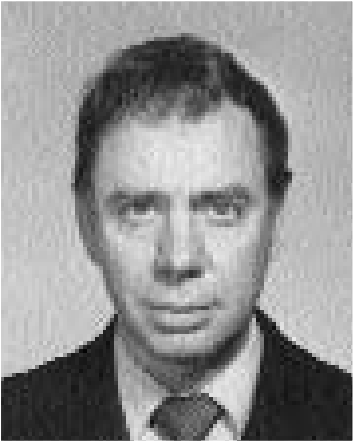

Walter S. Snyder is co-director of the Permian Research Institute, Boise State University and Professor in the Department of Geosciences. He has worked on a variety of Upper Paleozoic stratigraphic and structural problems while a graduate student at Stanford University (19721977), a Research Associate at Lamont-Doherty Earth Observatory of Columbia University (1977-1981), a Research Scientist with Phillips Petroleum Company (1981-1984), and at Boise State University (since 1984). His research interests include regional tectonics, basin analysis and sequence stratigraphy. He is a Corresponding Member of the Subcommission on Permian Stratigraphy.

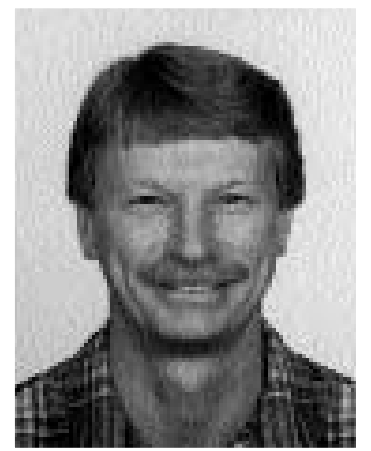

\section{Hutchison 'Young scientist' Fund}

William Watt Hutchison, "Hutch" to his many friends around the world, was a Scots-born Canadian geologist who served Canada and the IUGS in myriad dynamic and creative ways. Most notably, he served as the IUGS Secretary General (1976-1980) at a pivotal time in its history, and as IUGS President (1984-1987). The same boundless energy, enthusiasm, skill in communications, and ability to foster teamwork that characterized his work with the IUGS also carried him to preeminent scientific administrative positions in the Canadian Government, where he served as Director General of the Geological Survey of Canada and as Assistant Deputy Minister of Earth Sciences. His distinguished career was terminated in 1987 by his untimely death at the age of 52, following a painful struggle with cancer.

One of Hutch's last wishes was to establish under IUGS auspices a memorial foundation intended to promote the professional growth of deserving, meritorious young scientists from around the world by supporting their participation in important IUGS-sponsored conferences. The first 3 beneficiaries of the Hutchinson "Young Scientist Foundation" attended the 28th International Geological Congress (IGC) in Washington, D.C., in 1989.

Currently, income earned as interest on the Hutchison fund is insufficient to sustain comparable grants every four years without seriously eroding the principal. For that reason, the IUGS made no grants from the fund for the 30th IGC, preferring instead to strengthen the fund by allowing it to earn interest for a longer period of time and by appealing for donations from the international geologic community. It is expected that grants from the fund will again support deserving young scientists to attend the 31st IGC in the year 2000. The Hutchison "Young Scientist Foundation" is a worthy cause that honors a fine, caring man and a distinguished, public-spirited scientist and administrator. The foundation also celebrates and promotes those things that gave Hutch the most professional satisfaction: geology, international scientific collaboration, and stimulating young minds.

The IUGS welcomes contributions to the Hutchison "Young Scientist Foundation." Please send donations to:

$$
\begin{aligned}
& \text { Dr. John A. Reinemund } \\
& \text { P.O. Box 890 } \\
& \text { Leesburg, VA } 20178 \text { USA } \\
& \text { Fax: +1 } 7037774463 \\
& \text { Tel: +1 } 7037771491
\end{aligned}
$$

Checks in US dollars or Visa/Mastercard (please include account number and expiration date) are preferred in order to avoid the high cost of currency conversions. Residents of the U.S.A. are reminded that charitable gifts of this nature are tax deductible. 